\title{
PENGARUH GOOD CORPORATE GOVERNANCE DAN PRUDENT AKUNTANSI TERHADAP NILAI PERUSAHAAN PADA PERUSAHAAN MANFAKTUR 2014-2017
}

\author{
Basuki, Indra Gunawan Siregar \\ Universitas Muhammadiyah Tangerang \\ mr.basuki.tng@gmail.com, gunawan.sloww@yahoo.co.id,
}

\begin{abstract}
This study aims to find out empirically how empirical governance factors consist of managerial ownership, institutional ownership, board of commissioners' size and prudent accounting for the increase in firm value. The presence of corporate governance in the recovery of the crisis in Indonesia is absolutely necessary. The population used in this study are manufacturing companies listed on the Indonesia Stock Exchange for the period 2014-2017. The sampling method used was purposive sampling with predetermined criteria based on research variables

The results of this study indicate that managerial ownership variables, institutional ownership and the size of the board of commissioners do not affect the value of the company. While prudent accounting has a significant negative effect on firm value.
\end{abstract}

Keyword: Managerial ownership, Institutional Ownership, board size, firm value.

\section{PENDAHULUAN}

Perusahaan merupakan organisasi yang terdiri dari atas kelompok orang yang bekerja untuk mencapai suatu tujuan. Kepentingan yang paling mendasar yaitu mendapatkan keuntungan serta kesejahteraan bagi para pemegang saham perusahaan. Peningkatan nilai perusahaan yang tinggi merupakan tujuan jangka panjang yang seharusnya dicapai perusahaan, yang akan tercermin dari harga pasar sahamnya, karena penilaian investor terhadap perusahaan dapat diamati melalui pergerakan saham perusahaan.

Nilai perusahaan akan dapat dilihat dari kemampuan perusahaan membayar deviden. Ada saatnya deviden tersebut tidak dibagikan oleh perusahaan karena perusahaan merasa perlu untuk menginvestasikan kembali laba yang diperolehnya. Besarnya deviden tersebut dapat mempengaruhi harga saham. Apabila deviden yang dibayar tinggi, maka harga saham cenderung tinggi sehingga nilai perusahaan juga tinggi dan jika deviden dibayarkan kepada pemegang saham kecil maka harga saham perusahaan yang membagikannya tersebut juga rendah. Kemampuan sebuah perusahaan membayar deviden erat hubungannya dengan kemampuan perusahaan memperoleh laba yang tinggi, maka kemampuan perusahaan akan membayar deviden juga tinggi. Dengan deviden yang besar akan meningkatkan nilai perusahaan (Harjito dan Martono, 2005).

Peningkatan nilai perusahaan bisa dicapai apabila manajemen perusahaan mampu menjalin kerja sama yang baik dengan pihak lain di dalam membuat keputusan-keputusan keuangan. Pihak lain tersebut diantaranya meliputi shareholder dan stakeholder. Apabila tindakan yang dilakukan manajer dan pihak lain tersebut dapat berjalan sebagaimana mestinya, maka permasalahan tidak akan terjadi diantara kedua belah pihak tersebut. Akan tetapi kondisi yang sesungguhnya, penyatuan kepentingan antara kedua belah pihak tersebut sering kali menemui masalah (Borolla, 2011). Adanya masalah diantara manajer dan pemegang saham disebut masalah agensi.

Salah satu mekanisme yang diharapkan dapat mengontrol biaya keagenan yaitu dengan menerapkan tata kelola perusahaan yang baik (good corporate governance). Ada empat mekanisme corporate governance yang sering dipakai dalam berbagai penelitian mengenai corporate governance yang bertujuan untuk mengurangi konflik keagenan, yaitu komite audit, komisaris independen, 
kempelikan institusional, kepemilikan manajemen (Rahmawati, 2007). Kepemilikan manajerial dimaksudkan untuk memberikan kesempatan manajer terlibat dalam kepemilikan saham sehingga dengan keterlibatan kedudukan manajer sejajar dengan pemilik perusahaan (pemegang saham). Dengan adanya kepemilikan saham yang besar oleh manajemen dapat mensejajarkan kepentingan manajer dan pemegang saham sehingga dapat mengurangi konflik keagenan, karena manajer akan termotivasi untuk meningkatkan kinerja dan bertanggung jawab meningkatkan kemakmuran pemilik atau pemegang saham (prinsipal) sehingga nilai perusahaan juga akan meningkat.

Kepemilikan institusional atau kepemilikan saham oleh investor yang berasal dari pihak luar perusahaan, seperti berasal dari sektor keuangan perusahaan efek, perusahan asuransi, perbankan, perusahaan investasi, dan dana pensiun (Aminudin, 2004). Dengan adanya kepemilikan saham yang besar oleh institusi maka akan mendorong peningkatan pengawasan (monitoring) yang lebih optimal dan efektif terhadap kinerja manajemen, sehingga dapat meminimalisasi konflik keagenan dan dapat meningkatkan nilai perusahaan (Haruman, 2007). Haruman (2008) menyatakan bahwa struktur kepemilikan perusahaan dapat mempengaruhi pencapaian tujuan perusahaan.

Semakin besar dan luas usaha suatu perusahaan, pemilik tidak bisa mengelola sendiri perusahaannya secara langsung sehingga memicu timbulnya masalah keagenan. Dewan komisaris memegang peranan yang sangat penting dalam perusahaan, terutama dalam pelaksanaan good corporate governance. Dewan komisaris merupakan suatu mekanisme mengawasi dan mekanisme untuk memberikan petunjuk dan arahan pada pengelola perusahaan (FCGI, 2001). Komposisi dewan komisaris merupakan salah satu karakteristik dewan yang berhubungan dengan kandungan informasi laba. Melalui perannya dalam menjalankan fungsi pengawasan, komposisi dewan dapat mempengaruhi pihak manajemen dalam menyusun laporan keuangan sehingga dapat diperoleh suatu laporan laba yang berkualitas (Budiono, 2005).

Salah satu prinsip dasar yang dianut dalam akuntansi adalah prinsip prudent (conservatism). Pengaruh prudent terhadap nilai perusahaan diduga diinteraksi variabel GCG. Komitmen pihak internal perusahaan dalam memberi informasi yang transparan, akurat dan tidak menyesatkan investor merupakan salah satu indikator dalam melihat tingkat prudent dalam pelaporan keuangan suatu perusahaan. Sikap konservatif mengandung kesediaan mengorbankan sesuatu untuk mengurangi atau menghilangkan resiko terjelek dalam ketidak pastian (Suwardjono, 2013). Jika akuntansi menganut konsep dasar prudent dalam menyikapi ketidakpastian, maka akan diterapkan perlakuan atau prinsip akuntansi yang didasarkan pada munculan yang dianggap kurang menguntungkan. Tjhen, dkk (2012) menemukan prudent akuntansi mempengaruhi nilai perusahaan.

\section{LANDASAN TEORI}

\section{Agency Theory}

Inti dari hubungan keagenan adalah adanya pemisahan antara kepemilikan (di pihak principal/investor) dan pengendalian (di pihak agent/manajer). Adanya pemisahan kepemilikan oleh principal dengan pengendalian oleh agen dalam sebuah organisasi cenderung menimbulkan konflik keagenan di antara principal dengan agen (Siallagan dan Machfoedz, 2006). Menurut Darmawati, dkk (2004) mengatakan teori keagenan ditekankan untuk mengatasi dua permasalahan yang dapat terjadi dalam hubungan keagenan. Pertama, adalah masalah keagenan yang timbul pada saat keinginankeinginan atau tujuan-tujuan dari prinsipal dan agen berlawanan serta merupakan suatu hal yang sulit atau mahal bagi prinsipal untuk melakukan verifikasi tentang apa yang benar-benar dilakukan oleh agen. Kedua, adalah masalah pembagian resiko yang timbul pada saat prinsipal dan agen memiliki sikap yang berbeda terhadap resiko. Dengan demikian, prinsipal dan agen mungkin memiliki preferensi tindakan yang berbeda dikarenakan adanya perbedaan preferensi terhadap resiko. Konflik keagenan dapat dikurangi dengan mekanisme pengawasan. Mekanisme pengawasan yang dapat mengurangi konflik kepentingan antara principal dan agent dikenal dengan mekanisme good corporate governance.

\section{Signaling Theory}

Teori sinyal membahas mengenai dorongan perusahaan untuk memberikan informasi kepada pihak eksternal. Dorongan tersebut disebabkan karena terjadinya asimetri informasi antara pihak manajemen dan pihak eksternal. Untuk mengurangi asimetri informasi maka perusahaan harus mengungkapkan 
informasi yang dimiliki, baik informasi keuangan maupun non keuangan. Teori signal menurut Spence (1973) dapat disimpulkan merupakan sebuah asimetri informasi yang saling berkaitan antara pihak pengirim dan penerima, dimana pengirim memiliki informasi penuh sedangkan pihak penerima tidak memiliki informasi, kemudian pengirim informasi memberikan sinyal kepada penerima. Maksudnya adalah pihak pengirim yang memiliki data kondisi informasi perusahaan memberikan sinyal kepada pihak penerima dengan tujuan meyakinkan pihak penerima dengan kondisi kinerja perusahaan.

\section{Value Relevance Theory}

Relevansi nilai informasi akuntansi mempunyai arti kemampuan informasi akuntansi untuk menjelaskan nilai perusahaan ( Beaver, 1968). Penelitian mengenai value relevance menjadi penting karena terdapat klaim yang menyatakan bahwa laporan keuangan berbasis cost historis telah kehilangan sebagian besar relevansinya bagi investor yang diakibatkan oleh perubahan besar-besaran dalam perekonomian, yaitu dari perekonomian industrial ke perekonomian berteknolgi tinggi dan berorientasi jasa ( Francis dan schipper, 1998).

\section{Nilai Perusahaan}

Nilai perusahaan adalah sangat penting karena dengan nilai perusahaan yang tinggi akan diikuti oleh tingginya kemakmuran pemegang saham (Brigham dan Gapenski, 1996). Semakin tinggi harga saham semakin tinggi nilai perusahaan. Nilai perusahaan yang tinggi menjadi keinginan para pemilik perusahaan, sebab dengan nilai yang tinggi menunjukkan kemakmuran pemegang saham juga tinggi. Kekayaan pemegang saham dan perusahaan dipresentasikan oleh harga pasar dari saham yang merupakan cerminan dari keputusan investasi, pendananaan (financing) dan manajemen asset. Menurut Fama (1978) nilai perusahaan akan tercermin dari harga sahamnya. Harga pasar dari saham perusahaan yang terbentuk antara pembeli dan penjual disaat terjadi transaksi disebut nilai pasar perusahaan, karena harga pasar saham dianggap cerminan dari nilai asset perusahaan sesungguhnya. Nilai perusahaan yang dibentuk melalui indikator nilai pasar saham sangat dipengaruhi oleh peluang-peluang investasi. Adanya peluang investasi dapat memberikan sinyal positif tentang pertumbuhan perusahaan dimasa yang akan datang, sehingga akan meningkatkan harga saham, dengan meningkatnya harga saham maka nilai perusahaan pun akan meningkat.

\section{Good Corporte Governance Kepemilikan manajerial}

Salah satu elemen CG yang mempengaruhi insentif bagi manajemen untuk melaksanakan kepentingan terbaik dari pemegang saham adalah pemilikan saham oleh manajemen. Kepemilikan manajemen didefinisikan sebagai persentase saham yang dimiliki oleh manajemen secara aktif ikut dalam pengambilan keputusan perusahaan yang meliputi komisaris dan direksi (Midiastuty dan Machfoedz, 2003).

\section{Kepemilikan institusional}

Kepemilikan institusional memiliki kemampuan untuk mengendalikan pihak manajemen melalui monitoring secara efektif sehingga mengurangi tindakan manajemen melakukan manajemen laba. Persentase saham tertentu yang dimiliki oleh institusi dapat mempengaruhi proses penyusunan laporan keuangan yang tidak menutup kemungkinan terdapat akrualisasi sesuai kepentingan pihak manajemen.

\section{Ukuran dewan komisaris}

Ukuran dewan komisaris yaitu jumlah seluruh anggota dewan komisaris, baik yang berasal dari internal perusahaan maupun dari eksternal perusahaan. Total anggota dewan komisaris disesuaikan dengan apa yang tercantum dalam laporan tahunan perusahaan sampel. Dewan komisaris merupakan organ perusahaan yang bertugas melakukan pengawasan secara umum dan/atau khusus sesuai dengan anggaran dasar serta memberi nasihat kepada direksi.

\section{Prudent Akuntansi}

Konsep prudent menurut pengertian yang diberikan oleh FSAB (1980) Concepts Statement No. 2 par. 95 adalah " A prudent reaction to uncertainity to try to ensure that uncertainity and risk inherent in business situations are adequately considered". Sikap konservatif mengandung kesediaan mengorbankan sesuatu untuk mengurangi atau menghilangkan resiko terjelek dalam ketidakpastian (Suwardjono, 2013). Jika akuntansi menganut konsep dasar prudent dalam menyikapi ketidakpastian, maka akan diterapkan 
perlakuan atau prinsip akuntansi yang didasarkan pada munculan yang dianggap kurang menguntungkan. Berdasarkan Standar Akuntansi Keuangan terdapat beragam metode yang menerapkan prinsip prudent, antara lain PSAK No. 14 mengenai perhitungan biaya persediaan, PSAK No. 16 mengenai aktiva tetap dan penyusutan (2015), PSAK No. 19 mengenai amortisasi aktiva tidak berwujud dan PSAK No. 20 tentang biaya riset dan pengembangan.

\section{METODE PENELITIAN}

\section{Desain penelitian}

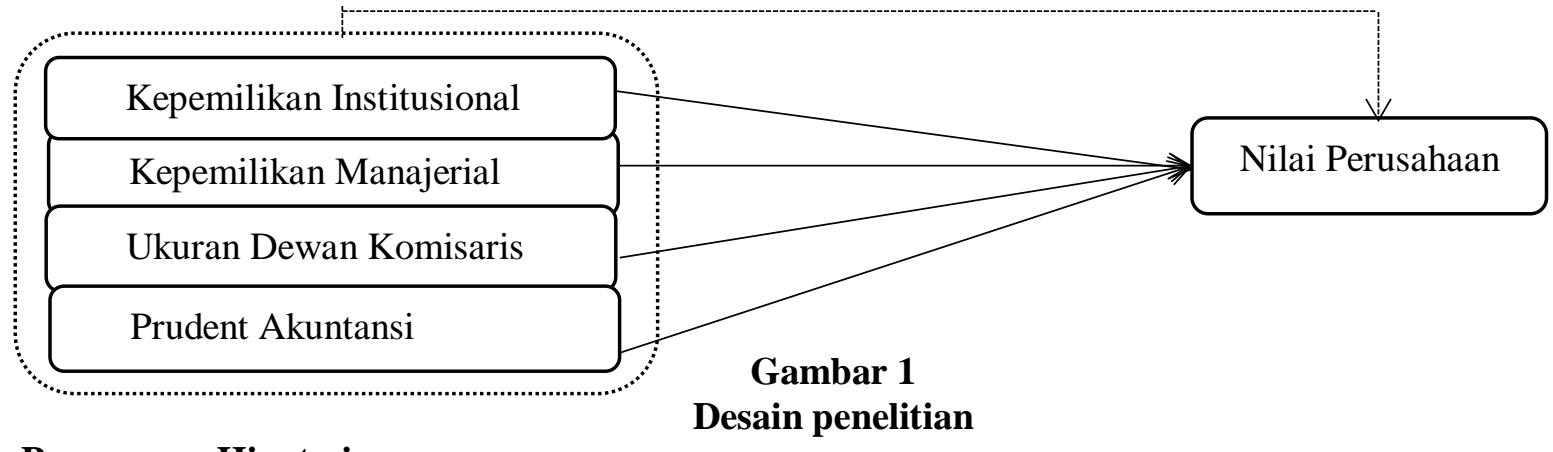

\section{Perumusan Hipotesis}

\section{Desain penelitian}

\section{Pengaruh Kepemilikan Manajerial terhadap Nilai Perusahaan}

Penelitian yang dilakukan Sofyaningsih dan Taswan (2002) menunjukkan hasil bahwa kepemilikan manajerial berpengaruh positif signifikan pada nilai perusahaan. Keefektifan kepemilikan manajerial dalam mengatasi konflik keagenan berkaitan dengan kepentingan manajemen untuk mengelola perusahaan secara efisien dalam rangka meningkatkan nilai perusahaan. Hasil penelitian ini sejalan dengan yang dilakukan oleh Rupilu (2011) menemukan bahwa kepemilikan manajerial berpengaruh terhadap nilai perusahaan. Susanti dkk (2010) menemukan bahwa kepemilikan manajerial berpengaruh terhadap nilai perusahaan. Sofyaningsih dan Hardiningsih (2011) menemukan bahwa kepemilikan manajerial terbutkti berpengaruh terhadap nilai perusahaan. Berdasarkan uraian di atas, maka hipotesis dalam penelitian adalah :

H1 : Terdapat pengaru kepemilikan manajerial terhadap nilai perusahaan

\section{Pengaruh Kepemilikan Institusional terhadap Nilai Perusahaan}

Penelitian yang dilakukan oleh Borolla (2011) menemukan bahwa kepemilikan institusional berpengaruh positif signifikan terhadap nilai perusahaan. Kepemilikan institusional dapat mengurangi masalah keagenan sebab timbulnya konsentrasi kepemilikan yang tinggi akan mendorong pemegang saham pada posisi yang kuat untuk mengendalikan manajemen secara efektif. Dengan adanya hal tersebut, maka diharapkan manajemen akan terdorong untuk bertindak sesuai dengan kepentingan pemegang saham. Penlitian tersebut sejalan dengan penelitian yang dilakukan oleh Rupilu (2011) menyebutkan bahwa kepemilikan institusional berpengaruh terhadap nilai perusahaan. Berdasarkan uraian di atas, maka hipotesis dalam penelitian ini adalah:

H2 : Terdapat pengaruh kepemilikan institusional terhadap nilai perusahaan.

\section{Pengaruh Ukuran Dewan Komisaris terhadap Nilai Perusahaan}

Dewan komisaris memegang peranan yang sangat penting dalam perusahaan terutama dalam pelaksanaan good corporate governance. Menurut FCGI (2001) dewan komisaris merupakan inti dari corporate governance yang ditugaskan untuk menjamin pelaksanaan strategi perusahaan, mengawasi manajemen dalam mengelola perusahaan serta mewajibkan terlaksananya akuntabilitas. Noorlaila (2011) menemukan bahwa ukuran dewan komisaris berpengaruh positif terhadap nilai perusahaan. Wardoyo dan Veronica (2013) menemukan bahwa ukuran dewan komisaris tidak memiliki pengaruh secara signifikan terhadap nilai perusahaan. Dewan komisaris merupakan organ perusahaan yang bertugas melakukan pengawasan secara umum dan/atau khusus sesuai dengan anggaran dasar serta memberi nasihat kepada direksi. Berdasarkan uraian di atas, maka hipotesis dalam penelitian ini adalah:

H3 : Terdapat pengaruh ukuran dewan komisaris terhadap nilai perusahaan

\section{Pengaruh Prudent Akuntansi terhadap Nilai Perusahaan}


Dalam upaya menghasilkan laporan keuangan yang baik, maka lahirlah prudent akuntansi. Menurut Thjen et al. (2012) mekanisme konservatisme akuntansi berpengaruh terhadap nilai perusahaan. Hasil ini berbeda dengan Florensia dan Jusny (2014) menemukan bahwa prudent akuntansi tidak berpengaruh terhadap nilai perusahaan. Berdasarkan uraian tersebut, maka hipotesis yang dikembangkan yaitu :

H4 : Terdapat pengaruh prudent akuntansi terhadap nilai perusahaan

Tabel 1

Opersional Variabel

\begin{tabular}{|c|c|c|c|c|}
\hline No. & Variabel & \multicolumn{2}{|l|}{ Pengukuran } & Skala \\
\hline 1 & $\begin{array}{l}\text { Kepemilikan } \\
\text { Manajerial }\end{array}$ & $\mathrm{KM}=\frac{\sum \text { Saham Manajerial }}{\sum \text { Saham Beredar }}$ & X 100\% & Rasio \\
\hline 2 & $\begin{array}{l}\text { Kepemilikan } \\
\text { Institusional }\end{array}$ & $\mathrm{KI}=\frac{\sum \text { Saham Institusi }}{} \underset{\sum \text { Saham Beredar }}{ }$ & X 100\% & Rasio \\
\hline 3 & $\begin{array}{l}\text { Ukuran } \\
\text { Dewan } \\
\text { Komisaris }\end{array}$ & UDK $=\sum$ Dewan Komisari & & Nominal \\
\hline 4 & $\begin{array}{l}\text { Prudent } \\
\text { Akuntansi }\end{array}$ & $\mathrm{AC}_{\text {it }}=\mathrm{NI} \mathrm{it}_{\text {it }}-\mathrm{CF}_{\text {it }}$ & & Rasio \\
\hline 5 & $\begin{array}{l}\text { Nilai } \\
\text { Perusahaan } \\
\text { (Tobin's } Q \text { ) }\end{array}$ & $\mathrm{Q}=\frac{((\mathrm{CP} * \mathrm{JS})+\mathrm{TL})-\mathrm{CA}}{\mathrm{TA}}$ & × 100\% & Rasio \\
\hline
\end{tabular}

\section{Metode Pengambilan Sampel}

Populasi dalam penelitian ini adalah perusahaan manufaktur sektor tekstil dan garment yang terdaftar di BEI periode tahun 2014-2017. Pengambilan sampel dalam penelitian ini dilakukan dengan menggunakan teknik non random sampling. Pemilihan sampel dengan metode purposive sampling dilakukan agar peneliti mendapatkan sampel yang representative sesuai kriteria yang ditentukan (Nurlela dan Islahuddin, 2008).

Metode Analisis Data

Analisis Statistik Deskriptif

Menurut Ghozali (2012) statistik deskriptif memberikan gambaran atau deskripsi suatu data yang dilihat dari nilai rata-rata (mean), standar deviasi, maksimum, minimum.

\section{Analisis Regresi}

Metode analisis yang digunakan adalah metode analsis kuantitatif yaitu untuk menganalisis informasi kuantitatif (dapat diukur, diuji dan ditransformasikan dalam bentuk persamaan, tabel dan sebagainya). Model analsis yang digunakan adalah model regresi data panel dengan metode least square yang bertujuan untuk mengetahui pengaruh variabel independen terhadap variabel dependen secara langsung.

\section{Teknik Penaksiran Model}

\section{Common Effect Model}

Menurut Sriyana (2014:108) sistematika model common effects adalah menggabungkan antara data time series dan data cross-section ke dalam data panel (pool data).

\section{Fixed Effect Model}

Menurut Sriyana (2014:121) kondisi data-data ekonomi pada tiap obyek yang dianalisis sangat mungkin saling berbeda, bahkan satu obyek pada suatu waktu akan sangat berbeda dengan kondisi obyek tersebut pada waktu yang lain.

\section{Random Effect Model}


Sriyana (2016:153) dapat dikatakan bahwa model random effects ini merupakan alternatif solusi jika fixed effects tidak tepat. Dibawah ini adalah uji yang dilakukan dalam memilih model yaitu :

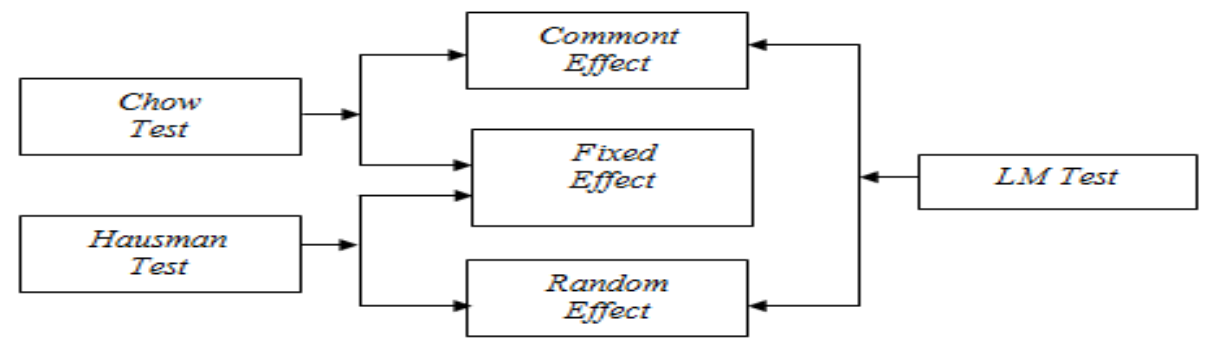

Gambar 2

Teknik pemilihan model

HASIL PENELITIAN

Hasil Uji Statistik Deskriptif

Tabel 2

Statistik Deskriptif

\begin{tabular}{|l|c|c|c|c|c|}
\hline & NP & KM & KI & UDK & PA \\
\hline Mean & 2.587647 & 0.019176 & 0.686029 & 2.264706 & 0.045882 \\
\hline Median & 0.975000 & 0.000000 & 0.670000 & 2.000000 & 0.060000 \\
\hline Maximum & 23.42000 & 0.240000 & 0.990000 & 4.000000 & 0.250000 \\
\hline Minimum & -0.160000 & 0.000000 & 0.290000 & 1.000000 & -0.100000 \\
\hline Std. Dev. & 4.137059 & 0.044149 & 0.174989 & 0.891379 & 0.081849 \\
\hline Skewness & 2.996589 & 2.936123 & 0.139986 & 0.604291 & 0.021920 \\
\hline Kurtosis & 13.26758 & 12.30916 & 1.893933 & 2.714898 & 2.583684 \\
\hline & & & & & \\
\hline Jarque-Bera & 400.4670 & 343.2405 & 3.688340 & 4.368864 & 0.496515 \\
\hline Probability & 0.000000 & 0.000000 & 0.158157 & 0.112542 & 0.780159 \\
\hline & & & & & \\
\hline Sum & 175.9600 & 1.304000 & 46.65000 & 154.0000 & 3.120000 \\
\hline $\begin{array}{l}\text { Sum Sq. } \\
\text { Dev. }\end{array}$ & 1146.722 & 0.130592 & 2.051628 & 53.23529 & 0.448847 \\
\hline Observations & 68 & 68 & 68 & 68 & 68 \\
\hline
\end{tabular}

Nilai perusahaan memiliki nilai mean sebesar 2,58 dan nilai minimum -0,16. Hasil ini mengindikasikan bahwa nilai perusahaan pada perusahaan sektor tekstil dan garment masih ada yang memiliki nilai kurang bagus di pasar. Nilai mean variabel kepemilikan manajerial memiliki nilai 1,9\%, mengindikasikan bahwa dengan adanya kepimilikan saham oleh manajer akan mendorongnya untuk bekerja sesuai dengan tujuan perusahaan, dan tanpa mementingkan kepentingan pribadi oleh manajer, dengan keadaan ini nilai perusahaan akan dapat meningkat. Kepemilikan institusional memiliki nilai 0,686 atau 68,6\%, menunjukkan bahwa rata-rata perusahaan sampel memiliki komposisi saham yang dimiliki oleh institusi atau lembaga. Ukuran dewan komisaris memiliki memiliki anggota dewan komisaris lebih dari 2 orang. Diharapkan tingkat pengawasan terhadap jalannya perusahaan akan lebih baik karena jumlah anggota dewan yang dimiliki lebih dari 50\% atau sudah melebihi kriteria yang sudah ditetapkan otoritas jasa keuangan dan diharapkan berimbas pada meningkatnya nilai perusahaan. Prudent akuntansi memiliki nilai rata-rata adalah 0,045, Artinya tidak semua perusahaan sektor tekstil dan garment melakukan tindakan prudent dalam pengungkapan laporan keuangan.

Pengujian hipotesis

Dependent Variable: NP 
Method: Panel EGLS (Cross-section random effects)

Date: 04/26/19 Time: 22:58

Sample: 20142017

Periods included: 4

Cross-sections included: 17

Total panel (balanced) observations: 68

Swamy and Arora estimator of component variances

\begin{tabular}{|c|c|c|c|c|}
\hline Variable & Coefficient & Std. Error & t-Statistic & Prob. \\
\hline $\mathrm{C}$ & -1.379109 & 1.512634 & -0.911727 & 0.3654 \\
\hline $\mathrm{KM}$ & 1.729920 & 4.656653 & 0.371494 & 0.7115 \\
\hline $\mathrm{KI}$ & 1.966480 & 1.668210 & 1.178797 & 0.2429 \\
\hline UDK & 0.629088 & 0.332035 & 1.894642 & 0.0627 \\
\hline $\mathrm{PA}$ & -1.590639 & 0.504165 & -3.154998 & 0.0025 \\
\hline \multicolumn{5}{|c|}{ Effects Specification } \\
\hline & & & S.D. & Rho \\
\hline Cross-section random & & & 1.110097 & 0.4352 \\
\hline Idiosyncratic random & & & 1.264536 & 0.5648 \\
\hline \multicolumn{5}{|c|}{ Weighted Statistics } \\
\hline R-squared & 0.218275 & \multirow{5}{*}{\multicolumn{2}{|c|}{$\begin{array}{l}\text { Mean dependent var } \\
\text { S.D. dependent var } \\
\text { Sum squared resid } \\
\text { Durbin-Watson stat }\end{array}$}} & -0.091923 \\
\hline Adjusted R-squared & 0.168642 & & & 1.360046 \\
\hline S.E. of regression & 1.240074 & & & 96.88037 \\
\hline F-statistic & 4.397746 & & & 1.416532 \\
\hline Prob(F-statistic) & 0.003369 & & & \\
\hline \multicolumn{5}{|c|}{ Unweighted Statistics } \\
\hline & 0.263616 & \multirow{2}{*}{\multicolumn{2}{|c|}{$\begin{array}{l}\text { Mean dependent var } \\
\text { Durbin-Watson stat }\end{array}$}} & -0.185735 \\
\hline Sum squared resid & 161.3136 & & & 0.850729 \\
\hline
\end{tabular}

Berdasarkan hasil uji analisis diatas maka dapat dibuat persamaan regresi dengan menggunakan model REM sebagai berikut :

$$
\mathrm{NP}=0,365+1,729 \mathrm{KM}+1,966 \mathrm{KI}+0,629 \mathrm{UDK}-1,59 \mathrm{PA}+\varepsilon
$$

\section{Uji F}

Berdasarkan tabel diatas maka ditarik kesimpulan bahwa uji $\mathrm{F}$ atau uji simultan pada penelitian ini menunjukkan bahwa secara simultan variabel independen (kepemilikan manajerial, kepemilikan institusional, ukuran dewan komisaris dan prudent akuntansi) berpengaruh terhadap nilai perusahaan. Dengan hasil ini maka model yang dipakai dalam penelitian ini dikatakan cocok dan bisa dilanjutakan dengan uji berikutnya.

Uji t

Berikuti ini adalah ringkasan hasil uji statistik $\mathrm{t}$ (parsial) yaitu :

Tabel 3

Ringkasan hasil 


\begin{tabular}{lccc}
\hline \multicolumn{1}{c}{ Variabel } & Sig & Hipotesis & Keterangan $\boldsymbol{\alpha}=\mathbf{5 \%}$ \\
\hline Kepemilikan manajerial & 0,711 & H1 ditolak & Tidak signifikan \\
Kepemilikan institusional & 0,242 & H2 ditolak & Tidak signifikan \\
Ukuran dewan komisaris & 0,062 & H3 ditolak & Tidak signifikan \\
Prudent akuntansi & 0,002 & H4 diterima & Signifikan \\
\hline
\end{tabular}

Pembahasan

Pengaruh Kepemilikan Manajerial Terhadap Nilai Perusahaan

Berdasarkan hasil statistik, kepemilikan manajerial tidak berpengaruh terhadap nilai perusahaan. Artinya, Keberadaan kepemilikan manajerial tidak efektif dalam mengatasi konflik keagenan berkaitan dengan kepentingan manajemen untuk mengelola perusahaan secara efisien dalam rangka meningkatkan nilai perusahaan pada sektor tekstil dan garment. Manajer sebagai mekanisme pengendali dalam penyusunan laporan laba kurang memberikan pengaruh kepada pasar melalui informasi laba dalam laporan keuangan sehingga nilai perusahaan tidak mengalami kenaikan. Hal ini di sebabkan kepemilikan saham oleh manajer yang sangat kecil pada perusahaan yaitu rata-rata 1,9\% saham. Dengan kepemilikan saham yang begitu kecil, maka sumber pendapatan atau capital gain yang akan diperoleh manajer juga akan kecil, dan akan lebih memilih sumber pendapatan lai melalui bonus dengan mempercantik laporan keuangan. Hal ini membuat manajer tidak bekerja sesuai dengan tujuan perusahaan, sehingga cenderung mementingkan kepentingan diri sendiri, imbasnya nilai perusahaan akan menurun.

Pengaruh Kepemilikan Institusional Terhadan Nilai Perusahaan

Berdasarkan hasil statistik, kepemilikan institusional tidak berpengaruh terhadap nilai perusahaan. Keberadaan pemegang saham institusi yang diharapkan memiliki kemampuan monitoring yang lebih baik tidak mampu membuat tata kelola perusahaan menjadi transparan. Artinya, kepemilikan saham yang besar oleh institusi tidak efektif dalam memonitor perilaku manajer dalam perusahaan. Ada indikasi pemegang saham institusi hanya mementingkan diri sendiri atau kepentingan institusinya tanpa melihat kepentingan pemegang saham yang lain. Keadaan ini akan memberi pengaruh yang besar pada menurunnya nilai perusahaan. Implikasinya, perusahaan tidak mampu memberikan informasi laporan keuangan yang fairness sehingga investor tidak akan bereaksi di pasar karena informasi laporan keuangan terdapat kandungan informasi bad news. Kepemilikan saham institusi yang mencapai $68 \%$ tidak memberikan dampak yang baik terhadap nilai perusahaan. Kondisi tersebut membuat pemegang saham lain beranggapan adanya ekspropriasi dari pemegang saham institusi dan menarik sahamnya dari perusahaan sehingga harga saham akan turun yang diikuti dengan menurunnya nilai perusahaan.

\section{Pengaruh Ukuran Dewan Komisaris Terhadap Nilai Perusahaan}

Berdasarkan hasil statistik, ukuran dewan komisaris tidak berpengaruh terhadap nilai perusahaan. Dewan komisaris yang ada di perusahaan belum melakukan peranannya dengan maksimal dalam mengawasi dan mengontrol jalannya kegiatan perusahaan. Artinya keberadaan dewan komisaris dengan rata-rata 2 anggota dewan komisaris masih terlalu lemah dalam melakukan fungsinya sebagai kontroler dan pengawas perusahaan, jumlah ini memang sudah sesuai dengan ketentuan peraturan OJK No. 33/POJK.04/2014. Sehingga tidak memberikan sinyal yang baik bagi para investor yang akan masuk. Kondisi ini dianggap tidak memberikan pengaruh yang baik terhadap nilai perusahaan. Fungsi pengawasan yang dilakukan dewan komisaris melalui rapat-rapat yang dilakukan tidak berjalan dengan baik atau tidak dilakukan dengan baik oleh perusahaan, sehingga terindikasi adanya ketidakharmonisan antara pihak perusahaan dengan dewan komisaris. Hasil ini juga tidak lepas dari adanya pergantian susunan dewan komisaris pada perusahaan, sehingga kinerja dewan komisaris tidak maksimal. Serta masih adanya perusahaan yang hanya memiliki 1 anggota dewan komisaris menjadi faktor yang memberikan lemahnya pengawasan terhadap perusahaan. Sehingga berimbas pada menurunnya nilai perusahaan.

Pengaruh Prudent Akuntansi terhadap Nilai Perusahaan 
Berdasarkan hasil statistik, prudent akuntansi berpengaruh negatif signifikan terhadap nilai perusahaan. Pelaporan keuangan perusahaan belum merefleksikan perusahaan yang sebenarnya. Artinya, ada indikasi perusahaan melakukan manajemen laba, sehingga di respon negatif oleh pengguna laporan keuangan. Hal ini berimbas pada menurunnya nilai perusahaan. Prudent akuntansi merupakan salah satu prinsip akuntansi yang diharapkan dapat meningkatkan nilai perusahaan melalui pelaporan informasi yang sesungguhnya, sehingga dapat direspon baik oleh penggunanya. Namun hasil penelitian menunjukkan hasil sebaliknya. Sikap konservatif yang mengandung kesediaan mengurangi resiko terjelek dalam ketidakpastian dengan melaporkan informasi pendapatan yang rendah dan melaporkan informasi beban yang tinggi direspon negatif oleh sebagian pengguna laporan keuangan. Karena dianggap kurang mengungtungkan bagi pihak tertentu. Salah satunya adalah investor spekulan atau investor jangka pendek yang mengharapkan laba yang tinggi dalam waktu yang cukup singkat.

\section{KESIMPULAN}

Berdasarkan hasil dan pembahasan, kesimpulan yang diperoleh adalah pertama, secara parsial hanya variabel prudent akuntansi yang berpengaruh negatif signifikan terhadap nilai perusahaan. Sedangkan variabel kepemilikan manajerial, kepemilikan institusional dan ukuran dewan komisaris tidak berpengaruh terhadap nilai perusahaan. Temuan dalam penelitian ini menunjukkan bahwa jumlah kepemilikan manajer yang kecil dan kepemilikan institusional yang besar tidak mampu mensejajarkan kepentingan manajemen dan pemegang saham, sehingga tujuan perusahaan dalam mencapai nilai perusahaan yang tinggi tidak tercapai. Saran untuk penelitian selanjutnya, sebaiknya menambah variabel independen lain yang dianggap berpengaruh terhadap nilai perusahaan. Dan diharapkan bagi perusahaan yang diteliti untuk mampu menerapkan GCG yang baik untuk meningkatkan nilai perusahaan.

\section{DAFTAR PUSTAKA}

Analisa, Yangs, 2011. Pengaruh Ukuran Perusahaan, Leverage, Profitabilitas dan Kebijakan Deviden Terhadap Nilai Perusahaan. Universitas Diponegoro. Semarang.

Dewi, Sri, Ayu dan Wirajaya, Ary, 2013. ISSN. Pengaruh Struktur Modal, Profitabilitas da Ukuran Perusahaan pada Nilai Perusahaan. Bali.

Haniati, Sri dan Fitriany, 2010. Pengaruh Konservatisme Terhadap Asimetri Informasi Dengan Menggunakan Beberapa Model Pengukuran Konservatisme. Universitas Indonesia.

Indriani, Eni, 2012. Distribusi Edisi ke XXXII. Mekanisme Corporate Governance sebagai pemoderasi antara Kualitas Laba dan Nilai Perusahaan. Universitas Mataram.

Mardiasari, Nilla, 2012. Universitas Islam Sunan Kalijaga. Pengaruh ROA Terhadap Nilai Perusahaan Dengan Pengungkapan GCG Sebagai Variabel Pemoderasi (Studi Pada Perusahaan yang Masuk Daftar Efek Syariah Periode 2007-2010). Yogyakarta.

Noorlaila, 2011. Analisis Pengaruh GCG Terhadap Nilai Perusahaan. UNDIP. Semarang.

Rahayu, Santi, 2012. Universitas Esa Unggul. Moderasi Auditor Terhadap Faktor-Faktor yang Mempengaruhi Auditor Switching pada Perusahaan Industri Manufaktur Yang Terdaftar Di BEI Pada Tahun 2006-2010. Jakarta.

Ratih, Suklimah, 2011. Jurnal Kewirausahan. Pengaruh GCG Terhadap Nilai Perusahaan Dengan Kinerja Keuangan Sebagai Variabel Intervening pada Perusahaan Peraih The Indonesian Most Trusted Company-CGPI. ISSN, 1978-4724. 
Retno, Reny, Dyah dan Priantinah, 2012. Universitas Negeri Yogyakarta. Pengaruh Good Corporate Governance dan Pengungkapan CSR Terhadap Nilai Perusahaan. Yogyakarta.

Sambora, dkk, 2014. Jurnal Administrasi Bisnis. Pengaruh Leverage dan Profitabilitas terhadap Nilai Perusahaan. Malang.

Sari, Enggar dan Riduwan, Akhmad, 2013. Jurnal Ilmu dan Riset Akuntansi. Pengaruh $C G$ Terhadap Nilai Perusahaan : Kualitas Laba sebagai Variabel Intervening. Surabaya.

Siahaan, Anton, Luvi, 2011. Jurnal Murni Sadar. Pengaruh Kinerja Keuangan Terhadap Nilai Perusahaan Dengan Pengungkapan CSR Dan GCG Sebagai Variabel Pemoderasi.

Suaidah, Sitta, 2010. Universitas Perbanas. Pengaruh ROA dan ROE Terhadap Nilai Perusahaan Dengan Pengungkapan CSR dan Kepemilikan Manajerial sebagai Pemoderasi. Surabaya.

Susanti, dkk. 2010. Simposium Nasional Keuangan. Analisis Pengaruh Mekanisme CG Terhadap Nilai Perusahaan Dengan Kualitas Laba sebagai Variabel Intervening pada Perusahaan Manufaktur yang Terdaftar di BEI Periode 2004-2007. Surakarta.

Suyanti, dkk, 2010. Universitas Sebelas Maret. Pengaruh Mekanisme CG Terhadap Nilai Perusahaan Dengan Kualitas Laba Sebagai Variabel Intervening. Surakarta.

Tjhen, Fabian, Tjandra, dkk, 2012. ISSN. Pengaruh Konservatisme Akuntansi Terhadap Nilai Perusahaan Dimoderasi Oleh GCG.

Wardoyo dan Veronica, Theodora, Martina, 2013. Jurnal Dinamika Manajemen. Pengaruh GCG, CSR dan Kinerja Keuangan Terhadap Nilai Perusahaan. Universitas Gunadarma. Jakarta. 